\title{
ECOLOGICAL AND PHYSIOLOGICAL VARIANCE IN T-CELL MEDIATED IMMUNE RESPONSE IN CORY'S SHEARWATERS
}

\author{
Manuela G. Forero ${ }^{1,6}$, Jacob González-Solis ${ }^{2}$, José M. IGual ${ }^{3}$, \\ KeITH A. Hobson ${ }^{4,5}$, XAVIER Ruíz ${ }^{2}$, AND Ginés VisCOR ${ }^{2}$ \\ ${ }^{1}$ Estación Biológica de Doñana (CSIC), Department of Applied Biology, Avda. María Luisa s/n, \\ Pabellón del Perú, 41013 Sevilla, Spain \\ ${ }^{2}$ Facultat de Biología, Universidad de Barcelona, Avda. Diagonal 645, 08028 Barcelona, Spain \\ ${ }^{3}$ Instituto Mediterráneo de Estudios Avanzados (CSIC-UIB), C/Miquel Marqués 21, 41960 Esporles, \\ Mallorca, Spain \\ ${ }^{4}$ Canadian Wildlife Service, 115 Perimeter Road, Saskatoon, SK S7N 0X4, Canada \\ ${ }^{5}$ Department of Biology, University of Saskatchewan, 112 Science Place, Saskatoon, SK S7N 5E2, Canada
}

\begin{abstract}
T-cell mediated immune response (CMI) has been widely studied in relation to individual and fitness components in birds. However, few studies have simultaneously examined individual and social factors and habitat-mediated variance in the immunity of chicks and adults from the same population and in the same breeding season. We investigated ecological and physiological variance in CMI of male and female nestlings and adults in a breeding population of Cory's Shearwaters (Calonectris diomedea) in the Mediterranean Sea. Explanatory variables included individual traits (body condition, carbon and nitrogen stable isotope ratios, plasma total proteins, triglycerides, uric acid, osmolarity, $\beta$-hydroxy-butyrate, erythrocyte mean corpuscular diameter, hematocrit, and hemoglobin) and burrow traits (temperature, isolation, and physical structure). During incubation, immune response of adult males was significantly greater than that of females. Nestlings exhibited a lower immune response than adults. Ecological and physiological factors affecting immune response differed between adults and nestlings. General linear models showed that immune response in adult males was positively associated with burrow isolation, suggesting that males breeding at higher densities suffer immune system suppression. In contrast, immune response in chicks was positively associated with body condition and plasma triglyceride levels. Therefore, adult immune response appears to be associated with social stress, whereas a trade-off between immune function and fasting capability may exist for nestlings. Our results, and those from previous studies, provide support for an asymmetrical influence of ecological and physiological factors on the health of different age and sex groups within a population, and for the importance of simultaneously considering individual and population characteristics in intraspecific studies of immune response.
\end{abstract}

Key words: body condition, breeding density, Calonectris diomedea, immunocompetence, physiological parameters.

\section{Varianza Ecológica y Fisiológica de la Respuesta Inmune Celular en Calonectris diomedea}

Resumen. La respuesta inmune mediada por linfocitos $\mathrm{T}$ (CMI) ha sido ampliamente estudiada en aves en relación a la variabilidad individual y los componentes de la eficacia biológica. Sin embargo, son pocos los estudios que han examinado simultáneamente la variación en inmunidad debida a factores individuales, sociales o relacionados con el tipo de hábitat, diferenciando entre pollos y adultos de la misma población y durante el mismo periodo reproductor. Hemos investigado la varianza ecológica y fisiológica en la CMI de adultos y pollos de ambos sexos en una población reproductora de Calonectris diomedea en el mar Mediterráneo. Entre las variables explicativas se incluyeron atributos individuales (condición física, niveles de isótopos estables de nitrógeno y carbono, proteínas totales, triglicéridos, ácido úrico, osmolaridad y $\beta$-hidroxybutirato plasmáticos, diámetro corpuscular medio eritrocitario, hematocrito y hemoglobina), así como atributos de las huras (temperatura, aislamiento y estructura física). Durante la incubación, la respuesta inmune de los adultos fue significativamente mayor en machos que en hembras. Los pollos mostraron una menor respuesta inmune que los adultos. Los factores ecológicos y fisiológicos que afectaron a la respuesta inmune difirieron entre adultos y pollos. Los modelos lineales generalizados mostraron que la respuesta inmune en machos adultos estuvo positivamente asociada con el grado de aislamiento de la hura, lo que

Manuscript received 6 September 2005; accepted 14 June 2006.

${ }^{6}$ E-mail: gforero@ebd.csic.es 


\begin{abstract}
sugiere que los machos que crían en altas densidades de conespecíficos sufren una depresión de su sistema inmunitario. En cambio, la respuesta inmune de los pollos estuvo positivamente asociada con su condición física y los niveles de triglicéridos en sangre. Así, la respuesta inmune de los adultos pareció estar parcialmente asociada con el estrés social, mientras que en los pollos puede existir un compromiso entre la función inmune y la capacidad de ayuno. Estos resultados y la comparación con los de estudios previos, sugieren la existencia de una asimetría en la influencia de los factores ecológicos y fisiológicos sobre la salud de las diferentes clases de edad y sexo en una población, así como la importancia de considerar simultáneamente características individuales y poblacionales en los estudios de respuesta inmune a nivel intraespecífico.
\end{abstract}

\section{INTRODUCTION}

The importance of T-cell mediated immune response (CMI), not only as a general indicator of health and condition, but also as an important life-history trait in birds, has become increasingly recognized and used as an analytical tool in avian studies (Martin et al. 2001, Tella et al. 2002). During the last decade, the skin test based on the proliferation of $\mathrm{T}$ lymphocytes in response to the injection of phytohemagglutinin (PHA) has become a common measure of the CMI of birds in many ecological and evolutionary studies (Smits et al. 1999). This methodological improvement has accommodated a growing interest in identifying the environmental factors and individual attributes that influence intraand interspecific variation in CMI. Among environmental conditions, the most frequently described effects are those of food resource availability and predictability (Tella et al. 2000, Hoi-Leitner et al. 2001, Cucco et al. 2002, Lifjeld et al. 2002), exposure to parasites (Christe et al. 2000, Møller and Rózsa 2005), and cold or heat stress (Lifjeld et al. 2002). Conspecific density, through its influence on social stress, has also been suggested as a factor affecting CMI (Tella et al. 2001). On an individual level, previous studies have found differential immune competence of males and females (Møller et al. 1998, Moreno et al. 2001, Fargallo et al. 2002), of individuals of different size and body condition (Blanco et al. 2001, Tella et al. 2001, Jovani et al. 2005), and relationships between physiological condition and immune capacity (Moreno et al. 1998). Previous work has also shown some genetic control on the immune system (Cheng and Lamont 1988). Intra- or interspecific approaches dealing with the differential effects of factors affecting CMI in chicks and adults are less common (but see Tella et al. 2001, Fargallo et al. 2002).
In this study, we examined environmental and individual factors that could affect immune response in Cory's Shearwaters (Calonectris diomedea). Extreme life-history characteristics and coloniality of seabirds in general, and of Cory's Shearwater in particular, make seabirds suitable species to study variability and evolution of CMI. However, CMI has been studied previously only in the Chinstrap Penguin (Pygoscelis Antarctica; Moreno et al. 1998), Magellanic Penguin (Spheniscus magellanicus; Moreno et al. 2001, Tella et al. 2001), Yellow-legged Gull (Larus cachinnans; AlonsoAlvarez and Tella 2001, Esparza et al. 2004), Inca Tern (Larosterna inca; Velando et al. 2001), and European Storm-Petrel (Hydrobates pelagicus; Esparza et al. 2004; see review by Tella et al. 2002). Here, we investigate the intraspecific variability of CMI in relation to: (1) individual characteristics such as age, sex, and body condition, which have previously been shown to covary with immune response; (2) several serological and hematological variables as indicators of health and condition of individuals; (3) breeding effort, indicated by egg volume; (4) diet and feeding conditions, as measured by stable nitrogen and carbon isotope values in blood, since greater values in stable isotope signatures may indicate better diet quality, influencing CMI response; (5) habitat characteristics and nest density; and (6) seasonality (hatching date) of chicks (Sorci et al. 1997, Moreno et al. 1998). Finally, we explored if variability in CMI of adults was reflected in their breeding parameters (hatching and breeding success). Details of the variables examined are shown in Table 1. With this approach, we aimed to simultaneously investigate various factors that affect immune response of nestlings and adults of the same species and population in relation to a wide array of environmental and individual variables. 


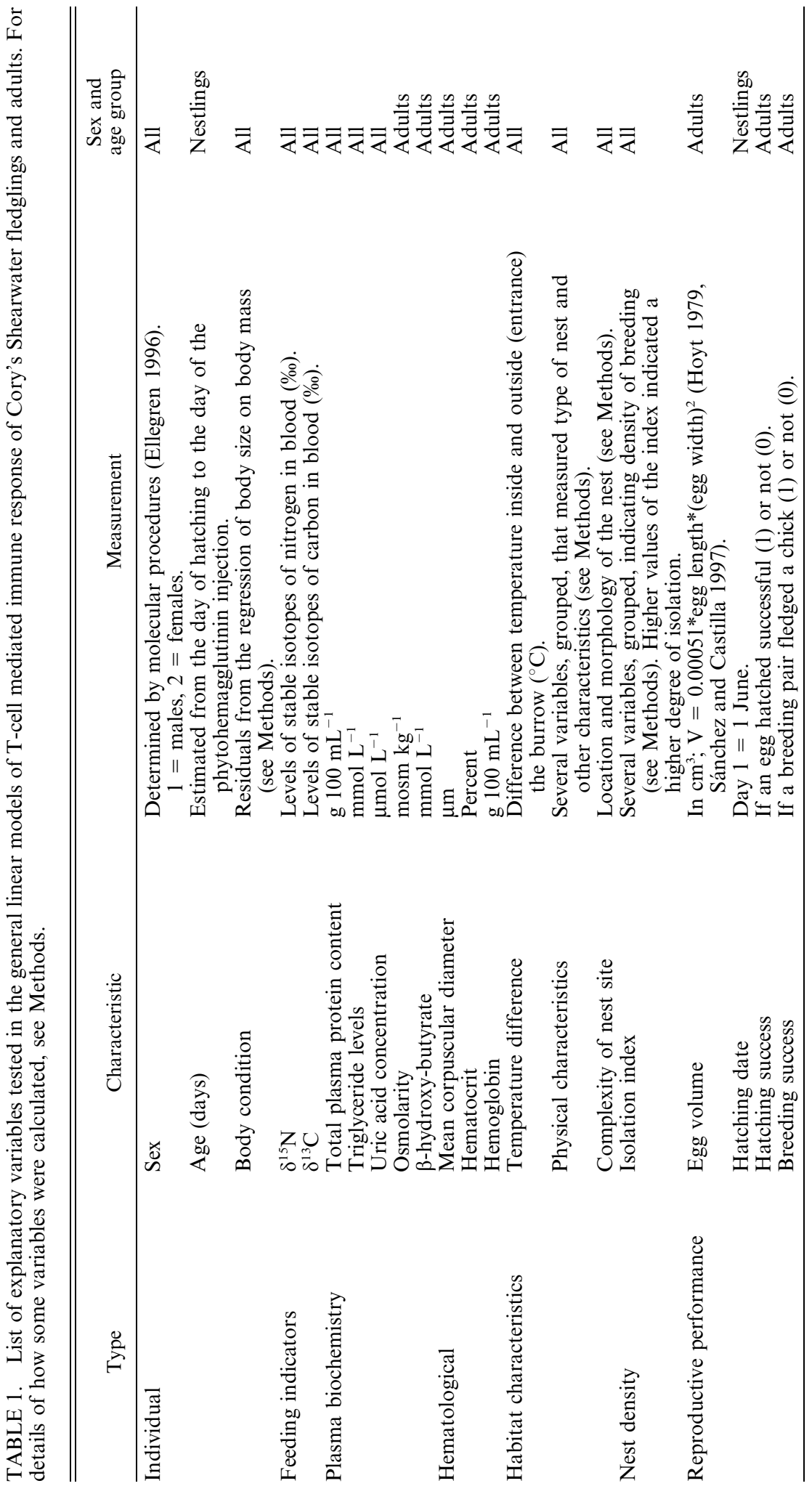




\section{METHODS}

\section{STUDY SITE, SPECIES, AND MONITORING}

The Mediterranean Cory's Shearwater is a procellariiform widely distributed in the northeast Atlantic Ocean and Mediterranean Sea (del Hoyo et al. 1992). It is sexually dimorphic, with males about $10 \%$ heavier than females (Thibault et al. 1997). The species lays a single-egg clutch and chicks develop slowly, with an average nestling period of about 90 days. Nestlings attain maximum weight at age 50 60 days. The study colony is on Congreso Island, located in the Chafarinas archipelago, $4.5 \mathrm{~km}$ off the Moroccan Mediterranean coast $\left(35^{\circ} 11^{\prime} \mathrm{N}, 3^{\circ} 46^{\prime} \mathrm{E}\right)$, and holds a minimum of 800-1000 breeding pairs (JMI and T. Gómez, Organismo Autónomo de Parques Nacionales, unpubl. data). Individuals arrive at the colony in March and their breeding period extends until October. At the study site, Cory's Shearwaters nest in cavities or crevices in cliffs, under boulders, or in short burrows in sandy soil with typical vegetation cover consisting of dry scrub (e.g., Salsola, Lycium, and Atriplex spp.). Breeding densities are also highly variable, ranging from one to 20 nests in $300 \mathrm{~m}^{2}$. The major identified cause of breeding failure in this colony, which has the lowest breeding success reported in the Mediterranean (Y. Aranda, J. Fernández, G. Garcia, and T. Gómez, Organismo Autónomo de Parques Nacionales, unpubl. data), is predation by introduced black rats (Rattus rattus), although there is considerable interannual variation in predation rates (Igual et al. 2006).

During 2001, we performed regular colony checks to measure eggs before hatching (maximum length and width to $\pm 0.1 \mathrm{~mm}$ with digital calipers) and estimate egg volume (Table 1), and determine hatching date, hatching success, age of the nestlings at sampling, and fledging success in most cases.

IMMUNOCOMPETENCE, STABLE ISOTOPE ANALYSES, HEMATOLOGY, AND BLOOD BIOCHEMISTRY

The skin test provides a measure of the proliferative response of circulating $\mathrm{T}$ lymphocytes to an injected mitogen (phytohemagglutinin, PHA). The main cellular response, measured as the amount of swelling $24 \mathrm{hr}$ after the injection, consists of a prominent perivascular accumulation of $\mathrm{T}$ lymphocytes followed by macrophage infiltration (Goto et al. 1978, Smits et al. 1999). Cory's Shearwater adults and nestlings were captured by hand on their nests during the incubation and nestling periods, respectively. We measured CMI by injecting $0.05 \mathrm{ml}$ of $2 \mathrm{mg} \mathrm{ml}^{-1}$ PHA (Sigma) in phosphate-buffered saline (PBS) into a marked site on the right external foot web. The thickness of the foot web was measured with a digital micrometer $( \pm 0.001 \mathrm{~mm})$ at the injection site, just prior to and $24 \mathrm{hr}$ after injection (Schrank et al. 1990, Navarro et al. 2003). Each time we measured the injection site we repeated the measurement three times to verify accuracy. CMI was calculated as the mean change in thickness between the day of injection and the following day (Tella et al. 2001). To reduce handling-related stress, we did not inject PBS into the left leg, since the response to injection of only PBS has been shown to be insignificant (Smits et al. 1999).

After measuring the CMI, up to $1 \mathrm{ml}$ of blood was taken from the foot vein. On some occasions it was not possible to obtain the entire sample volume, which limited the number of posterior analyses. About $0.2 \mathrm{ml}$ of this blood was transferred to two different vials, each containing $1 \mathrm{ml}$ of absolute ethanol. One of these samples was used for stable-isotope analyses as indicators of food regimes (see below), and the other for molecular sexing of individuals as described by Ellegren (1996).

Stable-isotope ratios of nitrogen $\left(\delta^{15} \mathrm{~N}\right)$ and carbon $\left(\delta^{13} \mathrm{C}\right)$ in the blood of seabirds reflect those in their prey in a predictable manner (DeNiro and Epstein 1978, 1981), giving information about trophic level and inshore vs. offshore foraging habits, respectively (Michener and Schell 1994, reviewed by Forero and Hobson 2003). Blood is a tissue with an integration period of about a month for large seabirds (Hobson and Clark 1992, Hobson 1993), and is thus useful for studies focused on discrete periods of time such as the breeding period. Following freeze drying of blood samples, $\delta^{13} \mathrm{C}$ and $\delta^{15} \mathrm{~N}$ assays were performed on $1 \mathrm{mg}$ subsamples of homogenized blood and measured by continuous-flow isotope-ratio mass spectrometry (CFIRMS) using a Europa 20:20 mass spectrometer (Europa Scientific, Crewe, UK). All isotope abundances are expressed in $\delta$-notation as parts per thousand (\%) deviation from atmospheric nitrogen 
TABLE 2. T-cell mediated immune response (CMI), feeding indicators, and hematological and plasma biochemistry values (means \pm SD) for chicks, adult females, and adult males of Cory's Shearwaters breeding at Chafarinas Island during 2001. Sample sizes are given in parentheses. Required sample volume limited the analyses of some parameters for some individuals, mainly for chicks for which some variables could not be analyzed.

\begin{tabular}{lccr}
\hline \hline \multicolumn{1}{c}{ Variable } & Adult females & Adult males & \multicolumn{1}{c}{ Chicks } \\
\hline $\mathrm{CMI}(\mathrm{mm})$ & $0.82 \pm 0.30(30)$ & $0.94 \pm 0.33(23)$ & $0.73 \pm 0.20(56)$ \\
$\delta^{15} \mathrm{~N}(\%)$ & $11.2 \pm 0.3(30)$ & $11.3 \pm 0.2(23)$ & $11.6 \pm 0.2(56)$ \\
$\delta^{13} \mathrm{C}(\%)$ & $-18.1 \pm 0.1(30)$ & $-18.1 \pm 0.2(23)$ & $-18.7 \pm 0.2(56)$ \\
Total plasma protein content & $3.38 \pm 0.53(26)$ & $3.56 \pm 0.49(21)$ & $3.39 \pm 0.38(55)$ \\
$\quad\left(\mathrm{g} 100 \mathrm{~mL}^{-1}\right)$ & $1.64 \pm 0.54(28)$ & $1.65 \pm 0.50(21)$ & $2.98 \pm 1.31(56)$ \\
Triglyceride levels $\left(\mathrm{mmol} \mathrm{L}^{-1}\right)$ & $304.17 \pm 186.34(25)$ & $267.77 \pm 114.90(20)$ & $434.91 \pm 257.83(54)$ \\
Uric acid concentration $\left(\mu \mathrm{mol} \mathrm{L}^{-1}\right)$ & $340.58 \pm 27.31(26)$ & $339.45 \pm 31.99(20)$ & \\
Osmolarity $\left(\mathrm{mosm} \mathrm{kg}^{-1}\right)$ & $1.61 \pm 1.28(28)$ & $1.42 \pm 0.81(21)$ & \\
$\beta$-hydroxy-butyrate $\left(\mathrm{mmol} \mathrm{L}^{-1}\right)$ & $5.97 \pm 0.21(30)$ & $6.05 \pm 0.28(21)$ & \\
Mean corpuscular diameter $(\mu \mathrm{m})$ & $42 \pm 4(30)$ & $40 \pm 7(23)$ & \\
Hematocrit $(\%)$ & $20.10 \pm 2.76(30)$ & $20.26 \pm 1.88(21)$ & \\
Hemoglobin $\left(\mathrm{g} 100 \mathrm{~mL}^{-1}\right)$ & &
\end{tabular}

$\left(\delta^{15} \mathrm{~N}\right)$ or Vienna Peedee Belemnite (VPDB, $\left.\delta^{13} \mathrm{C}\right)$ standards. Based on replicate measurements of an egg albumen laboratory standard, the analytical precision $( \pm \mathrm{SD})$ of these measurements is estimated to be $\pm 0.1 \%$ and $\pm 0.3 \%$ for carbon and nitrogen, respectively.

Of the total blood volume extracted, $0.8 \mathrm{ml}$ was stored at $4{ }^{\circ} \mathrm{C}$ in a $5 \mathrm{ml}$ vial with lithiumheparin. Within $3 \mathrm{hr}$ of extraction, $0.6 \mathrm{ml}$ was transferred to an Eppendorf tube and decanted for $4 \mathrm{hr}$ to separate the plasma from the cellular fraction. After this interval, one drop of plasma was used for determining total protein with a refractometer and the rest was frozen until determination of plasma osmolarity and triglyceride, uric acid, and $\beta$-hydroxy-butyrate levels. The remaining $0.2 \mathrm{ml}$ of whole blood was kept refrigerated until analyses of hematocrit, hemoglobin, and blood cell counts. Analyses were done 2-3 weeks after sampling. We mixed the blood in a roller mixer for $5 \mathrm{~min}$ and determined the hematocrit in a $70 \mu \mathrm{L}$ capillary tube after centrifugation for $7 \mathrm{~min}$ at $11500 \mathrm{rpm}$. Total hemoglobin was measured photometrically after hemolysis in Drabkin's solution. Blood cells were counted and measured with a Coulter Multisizer II (Coulter Electronics Ltd, Lutton, England). Triglyceride, uric acid, and $\beta$-hydroxy-butyrate levels were measured using Sigma standard kits (Sigma-Aldrich, St. Louis, Missouri) in a Spectronic $2000 \mathrm{UV}-\mathrm{Vis}$ spectrophotometer (Bausch and Lomb, Kingston upon Thames, UK). Plama osmolarity was measured with a $3 \mathrm{MO}$ microosmometer (Advanced Instruments, Nor- wood, Massachusetts). Measurements for some of these variables were not obtained for chicks due to restrictions in the volume of blood samples (Table 2).

\section{BODY SIZE AND BODY CONDITION INDEX}

Body measures of adults and nestlings (wing length, bill depth at nostril, maximum head length, tarsus length, and the length of the third flight feather, P3) were taken using digital calipers $( \pm 0.1 \mathrm{~mm})$ and a rule. Since individual body mass may vary among days depending on provisioning rates, we weighed individuals on two consecutive days, the day of the PHA injection and the following day.

Both adults and chicks of Cory's Shearwaters exhibit sexual size dimorphism (Bretagnolle and Thibault 1995; JMI and MGF, unpubl. data). Thus, for calculating a body size index, we used separate principal component analyses for male and female nestlings and adults. PC1 had the highest degree of correlation with body measurements and accounted for $72 \%$ and $76 \%$ of the total variance in size of adult males and females, respectively. For male and female chicks, $\mathrm{PC} 1$ accounted for only $46 \%$ and $41 \%$ of the variance in size, respectively. For adults, maximum head length showed the strongest correlation with our derived body size index for both sexes $(r=$ 0.94 and 0.89 in males and females, respectively), whereas bill length showed the strongest correlation with the derived index for nestlings $(r=0.76$ and 0.64 in males and females, respectively). 
The body condition index for adults was calculated as the residuals from the linear regression of body mass (minimum value from both measurements) of males and females on PC1 factor scores $\left(r=0.82, F_{1,22}=43.6, P<\right.$ 0.001 for males; and $r=0.85, F_{1,29}=72.6, P<$ 0.001 for females). When known, age of nestlings ranged from 63 to 81 days, with only two chicks younger than 75 days (mean = 75.9 days, $n=40$ ). Most chicks reached their peak mass within this age range, thus there was no correlation between mass and age for males $(r=-0.22, P=0.27)$ or females $(r=-0.34$, $P=0.25)$. Therefore, we calculated an index of nestling body condition by correcting body mass with respect to body size using the same statistical procedure applied for adults (males: $r=0.36, F_{1,33}=4.7, P=0.04$; females: $r=$ $\left.0.45, F_{1,21}=5.0, P=0.04\right)$.

\section{BREEDING SITE CHARACTERISTICS AND ENVIRONMENTAL CONDITIONS}

We included in our analyses a group of variables that described breeding density and nest-site characteristics. Previous research has demonstrated that density may affect immune condition through the effect of high stress mediated by food depletion around the colony or intraspecific social stress (Braude et al. 1999, Brinkhof et al. 1999, Tella et al. 2001). Thus, we measured two groups of variables for burrows: those related to the degree of breeding isolation and those related to the physical characteristics of the burrow. The first group of variables included position within the colony $(1=$ near the perimeter, 2 = intermediate, $3=$ central), density, measured by the number of breeding pairs within a radius of $5 \mathrm{~m}$ and $10 \mathrm{~m}$ of the nest, and distance to the nearest neighbor $(\mathrm{m})$. The second group of variables related to physical characteristics of the burrows and included nest complexity $(1=$ burrows in sandy soils without vegetation cover, $2=$ under bushes, $3=$ under boulders, $4=$ in crevices in cliffs, $5=$ in caves), straight-line distance to the sea $(\mathrm{m})$, altitude above sea level $(\mathrm{m})$, and plant cover $(\%)$ within a $4 \mathrm{~m}$ radius of the nest. In both cases selected variables could covary, so we performed categorical principal component analyses (CatPCA) to combine them and obtain an index of breeding isolation and an index of physical characteristics. In both analyses, we extracted the first component of CatPCA
(CatPCI), with eigenvalue contributions of $58 \%$ and $60 \%$, respectively. We also evaluated the effects of complexity of the nest burrow $(1=$ straight, $2=$ bent, $3=$ winding).

Ambient temperature and thermoregulatory properties of the nest site can affect the condition and immune response of adults and chicks through a differential cost of thermoregulation and investment in immunological functions (Lifjeld et al. 2002). Although ambient temperature could fluctuate greatly during the day and among days, we recorded the temperature outside and inside the burrow and calculated the difference between both values to measure the variability in conditions for thermoregulation.

\section{STATISTICAL ANALYSES}

We performed multivariate analyses to identify the effects of individual and environmental conditions (Table 1) on CMI of adults and chicks. Since factors affecting the immune response in chicks and adults could be different, and explanatory variables tested in each case differed slightly, we performed separate analyses for each age class. We fitted explanatory variables to the observed data using general linear models (GLM; Littell et al. 1996). Because CMI was normally distributed, we used the normal error and identity link functions of PROC GENMOD in SAS (SAS Institute 1997). Each explanatory variable and all possible interactions were fitted to the observed data following a forward stepwise procedure, which results in the most adequate model for explaining variation in the response variable by only retaining independent variables with significant effects (Forero et al. 2002). All tests were two-tailed with significance level set at $\alpha=0.05$. Descriptive statistics are expressed as mean \pm SD.

\section{RESULTS}

We measured the CMI of 53 adults and 56 chicks in 51 and 56 nests, respectively. In 23 of these nests we sampled both the chick and at least one of the parents. Univariate analyses indicated that incubating adults showed significantly higher levels of immunocompetence $(0.87 \pm 0.32 \mathrm{~mm})$ than nestlings $(0.73 \pm$ $0.20 \mathrm{~mm}$ ), and males showed greater CMI than females in both age classes (two-way ANOVA, age class: $F_{1,108}=10.0, P<0.01$; sex: $F_{1,108}=$ 


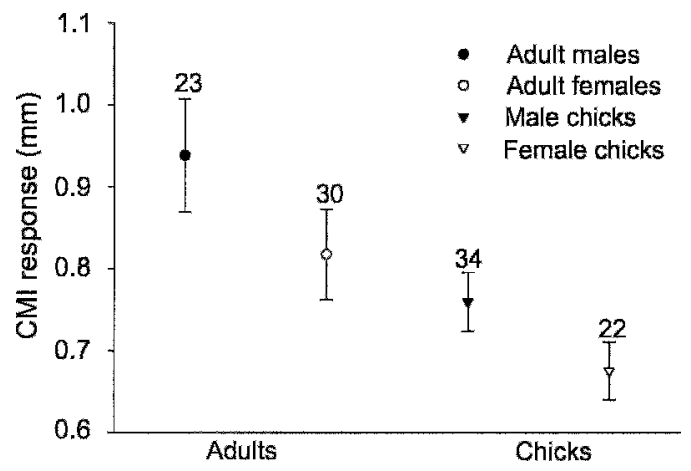

FIGURE 1. T-cell mediated immune response (CMI; means $\pm \mathrm{SE}$ ) was greater in adult males than adult females and greater in adults than in nestlings of Cory's Shearwaters in the Mediterranean Sea, 2001. Sample sizes are shown above error bars.

4.1, $P=0.04$; age*sex: $F_{1,108}=0.1, P=0.72$; Table 2, Fig. 1). The CMI of chicks was not related to that of their parents during incubation (Pearson correlation, $r=-0.35, n=$ 23, $P=0.10)$.

Results of the GLM showed different effects of the explanatory variables on CMI of chicks and adults. The best GLM for adult CMI explained $34 \%$ of the original deviance and revealed that CMI was related to the index of breeding isolation $(27 \%$ of the explained deviance, $\chi^{2}{ }_{1}=5.0, P=0.02$ ), and the interaction between sex and index of breeding isolation (57\% of the explained deviance, $\chi^{2}{ }_{1}=13.51, P$ $<0.001)$. Therefore, we also included sex in the model $\left(16 \%\right.$ of the explained deviance, $\chi^{2}{ }_{1}=$ 2.6, $P=0.07)$. As shown by the ANOVA analysis, males exhibited higher CMI than females, although the effect was only marginally significant. CMI was positively correlated with the breeding isolation index in males but not in females (Fig. 2), as indicated by the significant interaction between breeding isolation and sex. However, this significant effect was highly influenced by two males that bred in isolated burrows and had a high CMI.

The GLM for nestlings revealed that CMI was positively correlated with body condition $\left(\chi_{1}^{2}=12.1, P<0.001\right)$ and the level of blood triglycerides $\left(\chi^{2}{ }_{1}=6.6, P=0.01\right.$; Fig. 3a, 3b). Although sex was significant at some preliminary step of the model, showing the same trend as in adults (males showed higher values than females), it was not retained as a significant effect in the final model. The final model

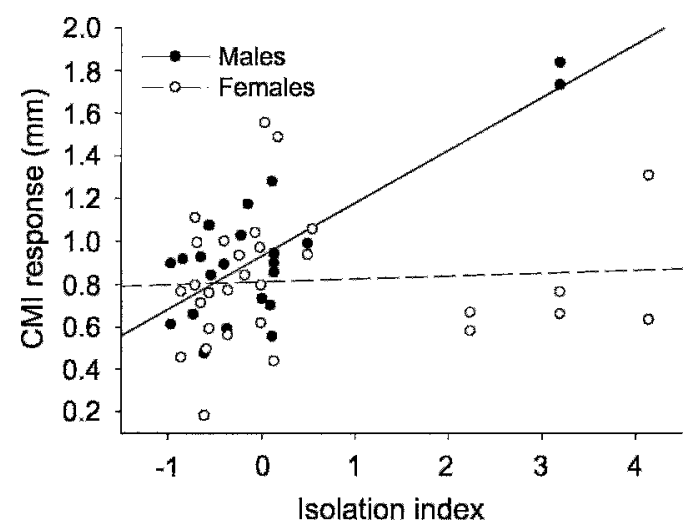

FIGURE 2. Male Cory's Shearwaters showed a positive relationship between nest isolation (first component from a categorical principal component analysis [CatPCI] for a group of variables related to the degree of breeding isolation of the burrow) and $\mathrm{T}$-cell mediated immune response (CMI). In contrast, female Cory's Shearwaters showed no relationship between nest isolation and CMI. Higher values of the nest isolation index indicate higher degrees of isolation.

accounted for only $28 \%$ of the original deviance, which was nearly equally explained by body condition $(62 \%$ of the total explained deviance) and blood triglycerides (38\%). Variables related to diet and feeding conditions, breeding effort, and seasonality were not included in any intermediate models or the final model for adults or chicks.

We also explored whether higher CMI in adult individuals during incubation was reflected in higher breeding parameters. To avoid noise introduced by chick and egg predation on the relationships between CMI and breeding performance, we excluded nests that had been depredated by rats (Igual et al. 2006). We did not find any significant relationship between the probability of hatching or breeding success and the immune response of males (MannWhitney $U$-tests, all $P>0.83$ ) or females (all $P$ $>0.25)$.

\section{DISCUSSION}

Our results help to address the present paucity of information on CMI reported for procellariiforms, an especially long-lived and reproductively conservative group of birds. CMI values of Cory's Shearwaters are among the lowest reported for any seabird (but see Esparza et al. 2004 for the Yellow-legged Gull). This result 

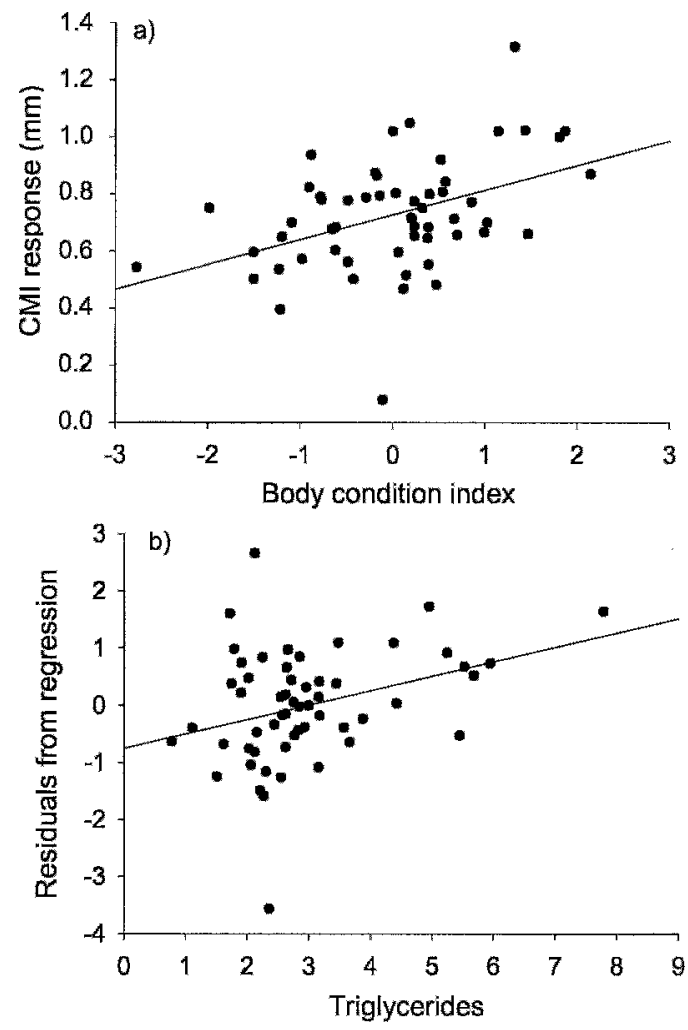

FIGURE 3. Nestling Cory's Shearwaters showed a positive relationship between $\mathrm{T}$-cell mediated immune response (CMI) and body condition index (residuals from a linear regression of body mass on body size; a). Residuals from the regression of CMI response and body condition (Fig. 3a) were also positively related to levels of blood tryglicerides (b).

does not support previous predictions of a strong immune system in species with long nesting periods and high ectoparasite loads, such as the Cory's Shearwater (Tella et al. 2002, Møller and Rózsa 2005) However, comparisons should be treated with caution as this result could be influenced by differences in PHA doses and ecological conditions among studies.

In Cory's Shearwaters, contrary to previous results in birds, nestlings showed lower CMI values than adults (Tella et al. 2001). Recently, Jovani et al. (2005) found high plasticity with respect to the relationship between individual variables and the CMI of White Storks (Ciconia ciconia) depending on environmental variation among years. Temporal variability in environmental factors during the breeding season and stage of the breeding cycle could also affect $\mathrm{CMI}$ of individuals and the relative response values of different age classes in the population. In our study, adults were sampled at the beginning of the breeding cycle, when the immune system probably was not yet depressed by breeding effort (Sheldon and Verhulst 1996), which could explain the higher CMI of adults compared to nestlings. This being true, comparisons of CMI among individuals from different populations or among different species should be interpreted with caution due to the effects of environmental variability and sampling conditions on CMI (Salvante 2006). Other factors affecting differences in CMI between age classes could include the amount of PHA injected relative to body mass, which in our study was lower in chicks than adults (mean weights of studied individuals: adult males, $721 \mathrm{~g}$; adult females, $650 \mathrm{~g}$; nestling males, $905 \mathrm{~g}$; nestling females, $811 \mathrm{~g}$ ).

Sexual differences in immune defense are common in birds, with males generally showing a weaker immune system (Zuk and McKean 1996, Møller et al. 1998). These differences are usually attributed to the effects of hormones, differential exposure to pathogens, or sex differences in resource allocation among immune function and other activities, such as differences in parental investment, competition for early arrival, or any activity related to sexual selection (Møller et al. 1998, Moreno et al. 1999, Duffy et al. 2000, Barbosa and Moreno 2002). In the case of cell-mediated immunity, most studies have reported greater CMI for females, in both adults and chicks (Moreno et al. 2001, Fargallo et al. 2002, Tschirren et al. 2003, Klein and Nelson 1998) or no differences between the sexes (Moreno et al. 1998, Saino et al. 2002, Lozano and Lank 2003, Møller et al. 2004). Since the studies reporting sexual differences include size-dimorphic and reversed size-dimorphic species, it has been suggested that sexual differences in CMI are associated with sex hormones rather than body size (Tschirren et al. 2003). However, we found a significantly greater CMI for adult males than adult females, and a similar trend in nestlings, even when males received a proportionately smaller PHA dose given their greater body size. To the best of our knowledge, this is the first study reporting a greater CMI in males, which is in conflict with the hypothesis of immunosuppressive effects of male hormones. 
Greater parasite loads can reduce CMI (Poiani et al. 2000), so differential exposure to parasites between males and females could lead to intersexual differences in CMI. However, in the Cory's Shearwater, males are more exposed to ectoparasites prior to egg-laying, since males spend more time in the burrow than females (Jouanin et al. 2001). Regardless, differential PHA response between the sexes is difficult to interpret adaptively without information on infestation levels.

Differential investment in activities related to sexual selection is also unlikely to apply, since sexual selection is likely weak in this species due to high social and sexual monogamy (Swatschek et al. 1994, Rabouam et al. 2000). Sexual differences in CMI could partly be explained by differential breeding investment of males and females. Investment in terms of incubation bouts or chick attendance and provisioning do not differ between individuals of a pair (Sánchez and Castilla 1997, Granadeiro et al 1998). However, we tested CMI a few days after eggs were laid. Egg production can be costly (Monaghan and Nager 1997), particularly for procellariiform females (Whittow 2002), which may result in some degree of immune system depression in this sex. However, the other physiological variables recorded in addition to CMI did not suggest differences in condition between males and females. The sexual differences we found could also be explained by changes in cell-mediated immunity during laying and incubation associated with a surge in estrogen production, which inhibits CMI in females (Grossman 1985, Astorquiza et al. 1987). Experimental studies are needed to disentangle these hypotheses.

Our general linear models indicated that factors affecting CMI of adults and chicks were different. The model for nestlings showed that body condition and levels of blood triglycerides were positively related to immune response. Body condition has been shown to be relevant to CMI of chicks and adults in previous observational (Tella et al. 2001, Jovani et al. 2005) and experimental studies (Brinkhof et al. 1999, Tella et al. 2000). Relationships between body condition and CMI in adult Cory's Shearwaters could be confounded by the strong oscillations in their mass over the incubation period. The relationship between triglycerides and CMI in nestlings is probably mediated by fasting periods. Adults feed chicks at irregular intervals and several days can pass before a chick receives a meal. High blood triglyceride levels are indicators of fattening periods; levels decrease during fasting and lower levels can indicate starvation (Jenni-Eiermann and Jenni 1998). Thus, lower CMI in fasting chicks shows that immune function is affected by nutritional state. This result indicates a trade-off between immune function and fasting capability, suggesting that chicks may be more vulnerable to pathogens after some days of fasting. This relationship supports the suggested role of the trade-off between investment in life-history components and investment in immunocompetence in determining optimal life-history traits (Norris and Evans 2000). The same relationship would be more difficult to find in adults because they should desert breeding duties before facing serious health deterioration.

Once sex was taken into account in multivariate analyses, the breeding isolation index explained most of the variability in CMI of adult males. Recent research has also shown a negative effect of breeding densities at different spatial scales on CMI of chicks (Tella et al. 2001), with the detrimental effect attributed to food depletion around the colony or social stress. In our study, competition in areas of high local breeding density may imply costs for males not sustained by females. In this species, the negative effect of high conspecific density, measured within a small radius around the nest, is probably due to higher rates of conspecific aggression among neighboring males rather than food limitation. Therefore, adult males at high local density may be immune-depressed because of a higher investment in nest defense. To cope with the required increase of energy supply to tissues for nest defense, the body probably reallocates energy from physiological functions such as immunocompetence (Adamo and Parsons 2006). Increased corticosterone is likely linking social stress with immunosuppression (Apanius 1998).

In this study we documented great individual variation in the immune response of Cory's Shearwaters and identified important individual and environmental factors affecting this parameter in the population. Previous work has demonstrated the complexity of the immune system and the need to perform several immune tests simultaneously to effectively 
measure immunocompetence (reviewed by Norris and Evans 2000, Adamo and Parsons 2006, Salvante 2006). We only measured one primary component of the immune system, but our test is a standardized challenge and measurement of immune response across individuals. Our findings of significant results may thus be regarded as reliable evidence of real individual variation in immunocompetence and that life-history decisions do have consequences for immunocompetence in the study species (Norris and Evans 2000). In this study, we did not find any consequences of immunocompetence on fitness. However, our negative results should not be considered conclusive, as we did not examine components of fitness other than breeding success (e.g., survival and lifetime reproductive success). Following Salvante (2006), we stress the need for more intraspecific studies on birds that control condition, physiological stage, environment, and other population characteristics while examining immunological traits. Only these approaches will allow for unbiased intra- and interspecific comparisons.

\section{ACKNOWLEDGMENTS}

We extend special thanks to T. Gómez and I. Afán at Gestión y Estudio de Espacios Naturales (GENA) and to J. Zapata from the Organismo Autónomo de Parques Nacionales (OAPN) of Spain for their invaluable help with the fieldwork and institutional and logistical support. J. Juste and R. Jovani improved the manuscript. Patricia Healy assisted with preparation of samples for stable isotope analysis, which were analyzed at the Department of Soil Science, University of Saskatchewan, Canada by D. Harris. MGF and JG-S were supported by a postdoctoral grant from Ministerio de Educación y Ciencia of Spain, a reincorporation grant from the Generalitat de Catalunya, a contract of the Program Ramón y Cajal of the Ministerio de Ciencia y Tecnología (MCyT) of Spain, and by Fondos FEDER. Additional financial support was provided by project REN2002-00450/GLO of MCyT and grant 2001SGR00091 from Generalitat de Catalunya.

\section{LITERATURE CITED}

AdAmo, S. A., AND N. M. Parsons. 2006. The emergency life-history stage and immunity in the cricket, Gryllus texensis. Animal Behaviour, in press.

Alonso-Álvarez, C., And J. L. Tella. 2001. Effects of experimental food restriction and body-mass changes on the avian T-cell-mediated immune response. Canadian Journal of Zoology 79:101-105

Apanius, V. 1998. Stress and immune defense, p. 133-153. In A. P. Møller, M. Millinski, and
P. J. B. Slater [EDS.], Stress and behaviour: advances in the study of behaviour. Vol 27. Academic Press, New York.

Astorquiza, M. I., C. Cisternas, And X. Leal. 1987. Sex-dependent differences in the $\operatorname{IgE}$ response modulated by phytohemagglutinin. Immunological Letters 16:27-30.

BarbosA, A., AND E. MorenO. 2002. Sex differences in T-cell-mediated immune response in Great Tits Parus major. Journal of Avian Science 2:99-102.

Blanco, G., J. de la Puente, M. Corroto, A. BAZ, AND J. COLAS. 2001. Condition-dependent immune defence in the Magpie: how important is ectoparasitism? Biological Journal of the Linnean Society 72:279-286.

Braude, S., Z. TAng-Martínez, And G. T. TAYLOR. 1999. Stress, testosterone, and the immuno-redistribution hypothesis. Behavioral Ecology 10:345-350.

Bretagnolle, V., AND J.-C. Thibault. 1995. Method for sexing fledglings in Cory's Shearwaters and comments on sex ratio variation. Auk 112:785-790.

Brinkhof, M. W. G., P. HeEb, M. Kollinger, AND H. RICHNER. 1999. Immunocompetence of nestling Great Tits in relation to rearing environment and parentage. Proceedings of the Royal Society of London Series B 266: 2315-2322.

Cheng, S., And S. J. LAmont. 1988. Genetic analysis of immunocompetence measures in a white leghorn chicken line. Poultry Science 67:989-995.

Christe, P., A. P. Møller, N. Saino, and F. DE LOPE. 2000. Genetic and environmental components of phenotypic variation in immune response and body size of a colonial bird, Delichon urbica (the House Martin). Heredity 85:75-83.

Cucco, M., R. Ottonelli, M. Raviola, And G. MALACARNE. 2002. Variations of body mass and immune function in response to food unpredictability in magpies. Acta Oecologica 23:271-276.

Del Hoyo, J., A. Elliott, and J. Sargata [eDs.]. 1992. Handbook of the birds of the world. Vol. 1. Lynx Edicions, Barcelona, Spain.

DeNiRo, M. J., AND S. EPSTEIN. 1978. Influence of diet on the distribution of carbon isotopes in animals. Geochimica et Cosmochimica Acta 42:495-506.

DENIRO, M. J., AND S. EPSTEIN. 1981. Influence of diet on the distribution of nitrogen isotopes in animals. Geochimica et Cosmochimica Acta 45:341-351.

Duffy, D. L., G. E. Bentley, D. L. Drazen, And G. F. BALL. 2000. Effects of testosterone on cellmediated and humoral immunity in non-breeding adult European Starlings. Behavioral Ecology 11:654-662.

Ellegren, H. 1996. First gene on the avian W chromosome (CHD) provides a tag for universal sexing of non-ratite birds. Proceedings of the Royal Society of London Series B 263: 1635-1641. 
Esparza, B., A. Martínez-Abraín, S. Merino, AND D. ORO. 2004. Immunocompetence and the prevalence of haematozoan parasites in two long-lived seabirds. Ornis Fennica 81:1-7.

Fargallo, J. A., T. LAaksonen, V. PÖYri, AND E. KORPIMÄKI. 2002. Inter-sexual differences in the immune response of Eurasian Kestrel nestlings under food shortage. Ecological Letters 5:95-101.

Forero, M. G., AND K. A. Hobson. 2003. Using stable isotopes of nitrogen and carbon to study seabird ecology: applications in the Mediterranean seabird community. Scientia Marina 67, supplement 2:23-32.

Forero, M. G., J. L. Tella, K. A. Hobson, M. Bertellotti, and G. Blanco. 2002. Conspecific food competition explains variability in colony size: a test in Magellanic Penguins. Ecology 83:3466-3475.

Goto, N., H. KodAma, K. OKadA, And Y. Fujimoto. 1978. Suppression of phytohemagglutinin skin response in thymectomized chickens. Poultry Science 57:246-250.

Granadeiro, J. P., M. D. Burns, And R. W. FURNESS. 1998. Patterns of activity and attendance in Cory's Shearwater Calonectris diomedea as revealed by a novel logging technique. Ibis 140:458-466.

Grossman, C. J. 1985. Interactions between the gonadal steroids and the immune system. Science 227:257-261.

Hobson, K. A. 1993. Trophic relationships among high Arctic seabirds: insights from tissue-dependent stable-isotope models. Marine Ecology Progress Series 95:7-18.

Hobson, K. A., And R. G. Clark. 1992. Assessing avian diets using stable isotopes II: factors influencing diet-tissue fractionation. Condor 94:189-197.

Hoi-Leitner, M., M. Romero-Pujante, H. Hoi, AND A. PAVlova. 2001. Food availability and immune capacity in Serin (Serinus serinus) nestlings. Behavioral Ecology and Sociobiology 49:333-339.

HoYT, D. F. 1979. Practical methods of estimating volume and fresh weight of bird eggs. Auk 96:73-77.

Igual, J. M., M. G. Forero, T. Gómez, J. F. ORueTA, AND D. ORO. 2006. Rat control and breeding performance in Cory's Shearwater (Calonectris diomedea): effects of poisoning effort and habitat features. Animal Conservation 9:59-65.

JENNI-EIERMANN, S., AND L. JENNI. 1998. What can plasma metabolites tell us about metabolism, physiological state and condition of individual birds? An overview. Biologia e Conservazione della Fauna 102:312-319.

Jouanin, C., F. Roux, J.-L. Mougin, And J.-C. STAHL. 2001. Prelaying exodus of Cory's Shearwaters (Calonectris diomedea borealis) on Selvagem Grande. Journal für Ornithologie 147: 212-217.

Jovani, R., J. L. Tella, G. Blanco, And M. BERTELLOTTI. 2005. Variable inter-annual rela- tionships between T-cell mediated immunity and individual life-history traits in White Storks. Ardeola 51:357-364.

Klein, S. L., AND R. J. Nelson. 1998. Adaptive immune responses are linked to the mating system of arvicoline rodents. American Naturalist 151:59-67.

LifJeld, J. T., P. O. DunN, And L. A. WhittingHAM. 2002. Short-term fluctuations in cellular immunity of Tree Swallows feeding nestlings. Oecologia 130:185-190.

Littell, R. C., G. A. Milliken, W. W. Stroup, AND R. D. WOLFINGER. 1996. SAS system for mixed models. SAS Institute, Inc., Cary, NC.

LozAno, G. A., AND D. B. LANK. 2003. Seasonal trade-off in cell-mediated immunosenescence in Ruffs (Philomachus pugnax). Proceedings of the Royal Society of London Series B 270: 1203-1208.

Martin, T. E., A. P. Møller, S. Merino, and J. Clobert. 2001. Does clutch size evolve in response to parasites and immunocompetence? Proceedings of the National Academy of Sciences USA 98:2071-2076.

Michener, R. H., AND D. M. SCHELl. 1994. Stable isotope ratios as tracers in marine and aquatic food webs, p. 138-157. In K. Lajtha and R. H. Michener [EDS.], Stable isotopes in ecology and environmental science. Blackwell Scientific Publications, Oxford, UK.

Møller, A. P., F. De Lope, And N. SAino. 2004. Parasitism, immunity, and arrival date in a migratory bird, the Barn Swallow. Ecology 85:206-219.

Møller, A. P., AND L. RÓzSA. 2005. Parasite biodiversity and host defenses: chewing lice and immune response of their avian hosts. Oecologia 142:169-176.

Møller, A. P., G. Sorci, And J. Erritzoe. 1998. Sexual dimorphism in immune function. American Naturalist 152:605-619.

Monaghan, P., And R. G. Nager. 1997. Why don't birds lay more eggs? Trends in Ecology \& Evolution 12:270-274.

Moreno, J., A. de León, J. A. Fargallo, And E. Moreno. 1998. Breeding time, health and immune response in the Chinstrap Penguin Pygoscelis antartica. Oecologia 115:312-319.

Moreno, J., J. PotTi, P. Yorio, and P. G. Borboroglu. 2001. Sex differences in cellmediated immunity in the Magellanic Penguin Spheniscus magellanicus. Annales Zoologici Fennici 38:111-116.

Moreno, J., J. J. SANZ, AND E. Arriero. 1999. Reproductive effort and T-lymphocyte cellmediated immunocompetence in female Pied Flycatchers Ficedula hypoleuca. Proceedings of the Royal Society of London Series B 266: 1291-1298.

Navarro, C., A. Marzal, F. De Lope, And A. P. Møller. 2003. Dynamics of an immune response in House Sparrows Passer domesticus in relation to time of day, body condition and blood parasite infection. Oikos 101:291-298. 
NORRIS, K., AND R. Evans. 2000. Ecological immunology: life history trade-offs and immune defense in birds. Behavioral Ecology 11:19-26.

Poiani, A., A. R. Goldsmith, And M. R. Evans. 2000. Ectoparasites of House Sparrows (Passer domesticus): an experimental test of the immunocompetence handicap hypothesis and a new model. Behavioral Ecology and Sociobiology 47:230-242.

Rabouam, C., V. Bretagnolle, Y. Bigot, and G. PERIQUET. 2000. Genetic relationships of Cory's Shearwater: parentage, mating assortment, and geographic differentiation revealed by DNA fingerprinting. Auk 117:651-662.

SAino, N., R. Ambrosini, R. Martinelli, S. Calza, A. P. Møller, and A. Pilastro. 2002. Offspring sexual dimorphism and sexallocation in relation to parental age and paternal ornamentation in the Barn Swallow. Molecular Ecology 11:1533-1544.

Salvante, K. G. 2006. Techniques for studying integrated immune function in birds. Auk 123:575-586.

SÁnCHeZ, A., AND A. DE CASTIlla. 1997. La Pardela Cenicienta (Calonectris diomedea) en las Islas Columbretes. Biología y Conservación. Excelentísimo Ajuntament de Castelló, Spain.

SAS INSTITUTE. 1997. SAS/STAT software, release 6.12. SAS Institute, Inc., Cary, NC.

SChrank, C. S., M. E. COOK, AND W. R. HANSEN. 1990. Immune response of Mallard Ducks treated with immunosuppressive agents: antibody response to erythrocytes and in vivo response to phytohemagglutinin-P. Journal of Wildlife Diseases 26:307-315.

Sheldon, B. C., AND S. Verhulst. 1996. Ecological immunology: costly parasite defences and tradeoffs in evolutionary ecology. Trends in Ecology \& Evolution 11:317-321.

Smits, J. E., G. R. Bortolotti, And J. L. Tella. 1999. Simplifying the phytohaemagglutinin skintesting technique in studies of avian immunocompetence. Functional Ecology 13:567-572.

Sorci, G., J. J. Soler, AND A. P. Møller. 1997. Reduced immunocompetence of nestlings in replacement clutches of the European Magpie
(Pica pica). Proceedings of the Royal Society of London Series B 264:1593-1598.

SwatscheK, I., D. Ristow, AND M. Wink. 1994. Mate fidelity and parentage in Cory's Shearwater Calonectris diomedea: field studies and DNA fingerprinting. Molecular Ecology 3:259-262.

Tella, J. L., G. R. Bortolotti, R. D. Dawson, AND M. G. Forero. 2000. The T-cell-mediated immune response and return rate of fledgling American Kestrels are positively correlated with parental clutch size. Proceedings of the Royal Society of London Series B 267:891-895.

Tella, J. L., M. G. Forero, M. Bertellotti, J. A. DonÁzar, G. Blanco, AND O. Ceballos. 2001. Offspring body condition and immunecompetence are negatively affected by high breeding densities in a colonial seabird: a multiscale approach. Proceedings of the Royal Society of London Series B 268:1-7.

Tella, J. L., A. Scheuerlein, AND R. E. Ricklefs. 2002. Is cell-mediated immunity related to the evolution of life-history strategies in birds? Proceedings of the Royal Society of London Series B 269:1059-1066.

Thibault, J.-C., V. Bretagnolle, And C. RaBOUAM. 1997. Calonectris diomedea Cory's Shearwater. BWP Update 1:75-98.

Tschirren, B., P. S. Fitze, AND H. Richner. 2003. Sexual dimorphism in susceptibility to parasites and cell-mediated immunity in Great Tit nestlings. Journal of Animal Ecology 72:839-845.

Velando, A., C. M. Lessells, AND J. C. Márquez. 2001. The function of female and male ornaments in the Inca Tern: evidence for links between ornament expression and both adult condition and reproductive performance. Journal of Avian Biology 32:311-318.

Whittow, G. C. 2002. Seabird reproductive physiology and energetics, p. 409-427. In E. A. Schreiber and J. Burger [EDS.], Biology of marine birds. CRC Press, Boca Raton, FL.

ZuK, M., AND K. A. MCKEAN. 1996. Sex differences in parasite infections: patterns and processes. International Journal for Parasitology 26: 1009-1024. 